\title{
A Cholecystokinin-Mediated Pathway to the Paraventricular Thalamus Is Recruited in Chronically Stressed Rats and Regulates Hypothalamic-Pituitary-Adrenal Function
}

\author{
Seema Bhatnagar, ${ }^{2}$ Victor Viau, ${ }^{1}$ Alan Chu, ${ }^{1}$ Liza Soriano, ${ }^{1}$ Onno C. Meijer, ${ }^{1}$ and Mary F. Dallman ${ }^{1}$ \\ ${ }^{1}$ Department of Physiology, University of California at San Francisco, San Francisco, California 94143-0444, and \\ 2Department of Psychology, University of Michigan, Ann Arbor, Michigan 48109
}

Chronic stress alters hypothalamic-pituitary-adrenal (HPA) responses to acute, novel stress. After acute restraint, the posterior division of the paraventricular thalamic nucleus (pPVTh) exhibits increased numbers of Fos-expressing neurons in chronically cold-stressed rats compared with stress-naïve controls. Furthermore, lesions of the PVTh augment HPA activity in response to novel restraint only in previously stressed rats, suggesting that the PVTh is inhibitory to HPA activity but that inhibition occurs only in chronically stressed rats. In this study, we further examined pPVTh functions in chronically stressed rats. We identified afferent projections to the pPVTh using injection of the retrograde tracer fluorogold. Of the sites containing fluorogold-labeled cells, neurons in the lateral parabrachial, periaqueductal gray, and dorsal raphe containing fluorogold also expressed cholecystokinin (CCK) mRNA. We then examined whether these CCKergic inputs to the pPVTh were involved in HPA responses to acute, novel restraint after chronic stress. We injected the CCK-B re- ceptor antagonist PD 135,158 into the PVTh before restraint in control and chronically cold-stressed rats. ACTH responses to restraint stress were augmented by PD 135,158 only in chronically stressed rats but not in controls. In addition, CCK-B receptor mRNA expression in the pPVTh was not altered by chronic cold stress. We conclude that previous chronic stress specifically facilitates the release of CCK into the pPVTh in response to acute, novel stress. The CCK is probably secreted from neurons in the lateral parabrachial, the periaqueductal gray, and/or the dorsal raphe nuclei. Acting via CCK-B receptors in PPVTh, CCK then constrains facilitated $\mathrm{ACTH}$ responses to novel stress in chronically stressed but not naïve rats. These results demonstrate clearly that chronic stress recruits a new set of pathways that modulate HPA responsiveness to a novel stress.

Key words: paraventricular thalamus; chronic stress; cholecystokinin; lateral parabrachial; ACTH; facilitation
Neuroendocrine responses to acute stress are modulated by previous experience with other stressful stimuli (Dallman and Bhatnagar, 2000). For example, previous chronic stress is associated with normal or enhanced responsiveness in the hypothalamic-pituitaryadrenal (HPA) axis to a novel stressor despite the negative feedback effects of circulating glucocorticoids produced by the chronic stressor (Ottenweller et al., 1989; Hauger et al., 1990; Young et al., 1990; Scribner et al., 1991; Bhatnagar and Meaney, 1995; Akana et al., 1996; Bhatnagar and Dallman, 1998). Furthermore, HPA responses can decrease with repeated exposure to the same stressor (Armario et al., 1986; Pitman et al., 1988; Odio and Brodish, 1989; Hauger et al., 1990; Viau and Sawchenko, 1995; Li and Sawchenko, 1998), and these effects are observable for months after the initial stress exposure (van Dijken et al., 1993). These effects of previous experience with stress cannot be fully explained by differences in glucocorticoid negative feedback efficacy and are likely caused by plastic changes in the brain produced by previous stress exposure (Dallman and Bhatnagar, 2000).

We have investigated the specific neuronal sites at which previous chronic stress may modify HPA responses to subsequent, novel stress. The paraventricular nucleus of the hypothalamus (PVN), the central, basomedial, and basolateral nuclei of the amygdala, the parabrachial/Kölliker-Fuse area, and the posterior division of the paraventricular nucleus of the thalamus (pPVTh) all exhibited increased neuronal activity in response to novel, acute stress in

Received Aug. 18, 1999; revised May 4, 2000; accepted May 5, 2000.

This research was funded by the National Institute of Diabetes and Digestive and Kidney Diseases Grant 28172 to M.F.D. S.B. was funded by a Medical Research Council of Canada postdoctoral fellowship and a National Alliance for Research on Schizophrenia and Depression Young Investigator award. We thank Allan Basbaum for discussions regarding data in this manuscript.

Correspondence should be addressed to Dr. Seema Bhatnagar, Department of Psychology, 525 East University, University of Michigan, Ann Arbor, MI 48109-1109. E-mail: bhatnags@umich.edu.

Copyright (C) 2000 Society for Neuroscience $0270-6474 / 00 / 205564-10 \$ 15.00 / 0$ chronically stressed compared with stress-naïve animals (Bhatnagar and Dallman, 1998). The PVTh is a midline thalamic nucleus receiving multimodal sensory input from the lateral parabrachial nucleus, the locus coeruleus, the nucleus tractus solitarius, and suprachiasmatic nuclei and projects to limbic sites such as the amygdala, nucleus accumbens, and frontal cortex (Fulwiler and Saper, 1984; Hunt et al., 1987; Moga et al., 1995; Otake and Nakamura, 1995). Neuronal activity in the PVTh (as measured by fos mRNA or Fos protein) is increased by exposure to a number of different stressors administered acutely, including swimming, restraint, ether, and foot shock (Chastrette et al., 1991; Sharp et al., 1991; Imaki et al., 1993; Cullinan et al., 1996). Furthermore, lesions of the entire PVTh increase ACTH responses to acute, novel stress only in rats exposed to previous chronic stress but do not affect responses in control, stress-naïve rats (Bhatnagar and Dallman, 1998). These data suggested that the PVTh is inhibitory to HPA activity but that inhibition occurs only in animals that had experienced previous stress. Thus, the PVTh is the only identified site at which previous stress experience acts to modify HPA responses to novel stress. Because of its well defined connections to limbic and sensory systems, it may also be a site at which previous stress modifies activity in other stress-sensitive systems.

In the present study we examined afferent inputs to the posterior PVTh that may be important for the regulation of HPA activity. We injected the retrograde tracer fluorogold into the pPVTh to identify brainstem projection sites to the pPVTh. Some of these identified sites are known to synthesize cholecystokinin (CCK), and the pPVTh expresses a moderate density of CCK-B receptors. Therefore, we next asked which of these sites of afferent input to the pPVTh synthesize CCK using combined fluorogold immunocytochemistry and in situ hybridization for CCK. Finally, we tested the functional relevance of the CCK input to the PVTh by measuring ACTH responses to acute restraint after blockade of CCK-B 
receptors in the PVTh in animals with and without previous experience with intermittent cold stress.

\section{MATERIALS AND METHODS}

\section{Animals}

Male Sprague Dawley rats (Bantin-Kingman, Gilroy, CA), weighing 200$225 \mathrm{gm}$ at arrival, were used for all experiments. Animals were singly housed, maintained on a 12:12 hr light/dark schedule (lights on at 6:30 hr) with access to food (Purina Rat Chow 5008) and water available ad libitum, and allowed at least $2 \mathrm{~d}$ to acclimate to the housing conditions before any manipulations were conducted. All experiments were approved by the University of California at San Francisco Committee on Animal Research.

\section{Chronic intermittent cold stress paradigm}

On each day of cold stress, animals were taken from their home cages and individually housed in polypropylene cages lined with bedding material with access to food and water. The cages were placed inside a well lit and well ventilated cold chamber maintained at $4-6^{\circ} \mathrm{C}$. The animals remained inside the cold chamber for $4 \mathrm{hr}$, generally from 13:00 to 17:00 hr, and then were returned to their home cages. This procedure was repeated every day for 7 consecutive days (CHR animals). Control animals (CTL) were left undisturbed throughout this time.

\section{Experiment 1: procedure}

Our specific goal was to target the pPVTh with the fluorogold injection because this is the division that exhibits increased Fos immunoreactivity after restraint in chronically stressed rats (Bhatnagar and Dallman, 1998). Twelve rats were anesthetized with a mix of ketamine, xylazine, and acepromazine (77:1.5:1.5 mg/ml, i.p., at $0.1 \mathrm{ml} / 100 \mathrm{gm}$ of body weight) and placed in a stereotaxic apparatus with the skull flat (the tooth bar at -3.3 $\mathrm{mm}$ ). A glass micropipette, filled with $3 \%$ fluorogold in $0.9 \%$ saline and with an external diameter between 30 and $100 \mu \mathrm{m}$, was lowered to the level of the PVTh, using the following coordinates: anteroposterior, $-3.3 \mathrm{~mm}$; dorsoventral, $-6.3 \mathrm{~mm}$. A pulse of $3 \mu \mathrm{A}$ current for 5 min was used to apply the fluorogold iontophoretically. After recovery from this surgery, the rats were returned to their home cages. Two weeks later, rats were perfused intracardially with $0.1 \mathrm{M}$ PBS followed by $4 \%$ paraformaldehyde. Brains were post-fixed in paraformaldehyde for $4 \mathrm{hr}$ and placed in $30 \%$ sucrose at least overnight. Multiple series of frozen coronal sections (30 $\mu \mathrm{m})$ throughout the brain were collected and stored in cryoprotectant (30\% ethylene glycol and $20 \%$ glycerol in $0.05 \mathrm{M}$ phosphate) at $-20^{\circ} \mathrm{C}$ until in situ hybridization and/or immunohistochemical processing.

\section{Detection of fluorogold-positive cells by immunocytochemistry}

This procedure identified neurons that projected to the pPVTh. A single series was immunocytochemically stained for fluorogold. Sections were rinsed in KPBS to remove cryoprotectant and incubated with rabbit polyclonal antisera (Chemicon, Temicula, CA) to fluorogold at a dilution of 1:8000 in KPBS and Triton X-100 containing 2\% BSA and $5 \mathrm{mg} / \mathrm{ml}$ heparin at $4^{\circ} \mathrm{C}$ for $48 \mathrm{hr}$. The tissue was then exposed to a goat anti-rabbit biotinylated secondary IgG diluted 1:200 (Vector Laboratories, Burlingame, CA) for $1 \mathrm{hr}$ and then to the avidin-biotin-peroxidase elite complex for $1 \mathrm{hr}$ at room temperature. To visualize fluorogold immunoreactivity, we used the AEC substrate kit (Vector Laboratories) that yields a red reaction product. Sections were washed in KPBS, mounted, and coverslipped using an aqueous medium. An initial global survey of the entire brain was used to identify regions expressing fluorogold-containing cells. Three rats were identified in this manner as having fluorogold injected into the medial/posterior division of the PVTh.

\section{Immunohistochemical and hybridization characterization}

This procedure was used to identify regions that were immunocytochemically stained for fluorogold and expressed CCK mRNA. A combination of fluorogold, visualized immunocytochemically with the DAB reaction, and in situ hybridization for CCK mRNA was used on a single series of sections through specific brain regions that were identified previously with the AEC staining described above. The AEC reaction product cannot withstand the temperatures and washes required for the in situ hybridization procedure. Therefore, fluorogold was histochemically characterized using DAB as the chromogen. Sections were immunocytochemically stained for fluorogold (as described above except all buffers were made with DEPC-treated water) and hybridized for CCK mRNA and an adjacent series was stained with cresyl violet to facilitate localization of structures.

Hybridization histochemical localization was performed using a ${ }^{33} \mathrm{P}$ labeled antisense cRNA probe transcribed from a full-length cDNA encoding CCK mRNA (Dr. John Walsh, University of California at Los Angeles, Los Angeles, CA). The techniques for riboprobe synthesis, hybridization, and autoradiographic localization of the mRNA signal were adapted according to the methods of Chan et al. (1993) and Watts and Swanson (1989). After immunocytochemistry for fluorogold using the DAB reaction, free-floating sections were first rinsed in $0.1 \mathrm{M}$ phosphate buffer, $\mathrm{pH}$ 7.4, and then mounted and vacuum dried on glass slides overnight. After post-fixation with $10 \%$ formaldehyde for $30 \mathrm{~min}$ at room temperature, slides were rinsed four times in KPBS for $7 \mathrm{~min}$ each at room temperature. Sections were digested with protease K $(250 \mu \mathrm{l}$ of $10 \mathrm{mg} / \mathrm{ml}$ stock in $250 \mathrm{ml}$ of buffer) for $30 \mathrm{~min}$ at $37^{\circ} \mathrm{C}$, rinsed once in DEPC-treated water for $3 \mathrm{~min}$, rinsed once in $0.1 \mathrm{M}$ triethanolamine (TEA; $2.5 \mathrm{~mm}$ acetic anhydride and $0.1 \mathrm{M}$ TEA, $\mathrm{pH} 8.0$ ) for $3 \mathrm{~min}$, acetylated for $10 \mathrm{~min}$ in TEA, rinsed in $2 \times$ SSC for 5 min, rapidly dehydrated by dipping in ascending ethanol concentrations $(50-100 \%)$, and then vacuum dried for at least $2 \mathrm{hr}$. Radionucleotide cRNA probes were used at concentrations approximating $10^{7} \mathrm{cpm} / \mathrm{ml}$ in a solution of $50 \%$ formamide, $0.3 \mathrm{M} \mathrm{NaCl}, 10$ mM Tris, $\mathrm{pH}$ 8.0, $1 \mathrm{~mm}$ EDTA, $10 \mathrm{~mm}$ dithiothreitol, $1 \times$ Denhardt's solution, and $10 \%$ dextran sulfate and applied to individual slides. Slides were coverslipped and then incubated overnight at $55^{\circ} \mathrm{C}$, after which the coverslips were removed and the sections were rinsed once in $4 \times \operatorname{SSC}(0.15$ $\mathrm{M} \mathrm{NaCl}$ and $15 \mathrm{~mm}$ citric acid, $\mathrm{pH}$ 7.0) at room temperature, treated with ribonuclease A $(14 \mu \mathrm{g} / \mathrm{ml}$ of $0.1 \mathrm{M}$ Tris, $0.5 \mathrm{M} \mathrm{NaCl}$, and $1 \mathrm{~mm}$ EDTA) for $30 \mathrm{~min}$ at $37^{\circ} \mathrm{C}$, incubated in buffer only for $30 \mathrm{~min}$ at $37^{\circ} \mathrm{C}$, incubated in $1 \times$ SSC with mild agitation for $15 \mathrm{~min}$ at room temperature, stringently washed in $0.5 \times \mathrm{SSC}$ for $30 \mathrm{~min}$ at $68^{\circ} \mathrm{C}$, and dehydrated by dipping in ascending ethanol concentrations. Sections hybridized with the ${ }^{33} \mathrm{P}$-labeled CCK cRNAs were then exposed to x-ray film (Hypermax MP; Amersham, Arlington Heights, IL) for $48 \mathrm{hr}$, defatted in xylenes, and subsequently coated with Kodak NTB2 liquid autoradiographic emulsion and exposed at $4^{\circ} \mathrm{C}$ in the dark with dessicant for $6 \mathrm{~d}$, as determined by the strength of the signal on the x-ray film. Slides were developed with Kodak D-19 for 5 $\mathrm{min}$ at $25^{\circ} \mathrm{C}$, rinsed vigorously in tap water, fixed in Kodak fixer for $5 \mathrm{~min}$, and washed in running water at room temperature for $30 \mathrm{~min}$. A qualitative analysis was used to determine cells that were labeled for fluorogold and CCK mRNA. A cell was considered CCK expressing if the density of grains was three times greater than background. Brain regions expressing fluorogold-containing cells from Experiment 1 were examined for CCKexpressing cells.

\section{Experiment 2: procedure}

In this experiment, one set of control and one set of chronically stressed animals were killed on day 8 under basal conditions. Brains were removed, embedded in OTC compound, frozen, and stored at $-80^{\circ} \mathrm{C}$. Brains were sliced at $15 \mu \mathrm{m}$ on a cryostat, and sections were stored at $-80^{\circ} \mathrm{C}$ until processing for in situ hybridization for CCK-B receptor expression. There were five animals per group in this study.

\section{In situ hybridization detection of $C C K-B$ receptors in the PVTh}

On the basis of the sequence of the CCK-B receptor gene (2243 bp in length) provided by Wank et al. (1992), we cloned a $372 \mathrm{bp}$ long portion of the CCK-B receptor from rat brain cDNA. The fragment was amplified with PCR (using primers for nucleotides 715-736 and 1065-1087). This sequence was cloned in a pBluescript vector, linearized with XbaI, and transcribed with T3 RNA polymerase. Frozen sections collected at $15 \mu \mathrm{m}$ were fixed with $4 \%$ paraformaldehyde for $5 \mathrm{~min}$ on ice, incubated in $0.1 \mathrm{M}$ PBS on ice for 2 min, rinsed briefly in $0.1 \mathrm{M}$ TEA, and acetylated in $0.1 \mathrm{M}$ TEA and acetic anhydride for $10 \mathrm{~min}$ at room temperature with vigorous stirring. The tissue was then rinsed in $2 \times$ SSC and dehydrated $2 \mathrm{~min}$ in ascending grades of ethanol. Last, sections were defatted in chloroform for $5 \mathrm{~min}$ at room temperature, dipped in $95 \%$ ethanol for $2 \mathrm{~min}$, and stored at room temperature.

$\left[{ }^{33} \mathrm{P}\right] \mathrm{UTP}-\mathrm{labeled}$ ribonucleotide cRNA probe was used at concentrations approximating $10^{7} \mathrm{cpm} / \mathrm{ml}$ in a solution of $50 \%$ formamide, $0.3 \mathrm{M}$ $\mathrm{NaCl}, 10 \mathrm{~mm}$ Tris, pH 8.0, $1 \mathrm{~mm}$ EDTA, $10 \mathrm{~mm}$ dithiothreitol, $1 \times$ Denhardt's solution, and $10 \%$ dextran sulfate and applied to individual slides. Slides were coverslipped, then incubated overnight at $55^{\circ} \mathrm{C}$, rinsed once in $4 \times$ SSC $(0.15 \mathrm{M} \mathrm{NaCl}$ and $15 \mathrm{~mm}$ citric acid, $\mathrm{pH} 7.0)$ at room temperature to remove the coverslips, treated with ribonuclease A (14 $\mu \mathrm{g} / \mathrm{ml}$ of $0.1 \mathrm{M}$ Tris, $0.5 \mathrm{M} \mathrm{NaCl}$, and $1 \mathrm{~mm}$ EDTA) for $30 \mathrm{~min}$ at $37^{\circ} \mathrm{C}$, desalted in $1 \times \mathrm{SSC}$ with mild agitation at room temperature, washed in $0.5 \times \mathrm{SSC}$ for $30 \mathrm{~min}$ at $68^{\circ} \mathrm{C}$, and dehydrated in ascending ethanol concentrations. Sections hybridized with the ${ }^{33} \mathrm{P}$-labeled CCK-B receptor cRNAs were then exposed to x-ray film (HyperFilm MP; Amersham) for $3 \mathrm{~d}$, subsequently coated with Kodak NTB2 liquid autoradiographic emulsion, and exposed at $4^{\circ} \mathrm{C}$ in the dark with dessicant for $15 \mathrm{~d}$, as determined by the strength of the signal on the x-ray film. Slides were developed with Kodak D-19 for $5 \mathrm{~min}$ at room temperature, vigorously dipped in tap water for $15 \mathrm{sec}$, and then dipped in Kodak fixer for $5 \mathrm{~min}$. Sections were then incubated in running tap water for 30 min and lightly stained with cresyl violet. Semiquantitative densitometric analysis of the levels of CCK-B receptor mRNA was performed, using Macintosh-driven NIH Image software (version 1.61; William Rasband, National Institutes of Health, Bethesda, MD), in three levels of the PVTh: the anterior $(-1.8 \mathrm{~mm}$ from bregma), middle $(-2.8 \mathrm{~mm}$ from bregma), and posterior $(-3.3 \mathrm{~mm}$ from bregma) divisions. At least two sections per level of PVTh per animal were analyzed.

\section{Experiment 3a: procedure}

All animals were allowed $48 \mathrm{hr}$ to acclimate to the housing conditions. Guide cannulae (28 ga; Plastic Products, Roanoke, VA) were implanted in all animals using the coordinates and procedure described below. All animals were allowed at least $48 \mathrm{hr}$ to recover from surgery. Animals were divided into two groups, control and chronically stressed. Chronically stressed animals were exposed to chronic, intermittent cold stress for $7 \mathrm{~d}$ 

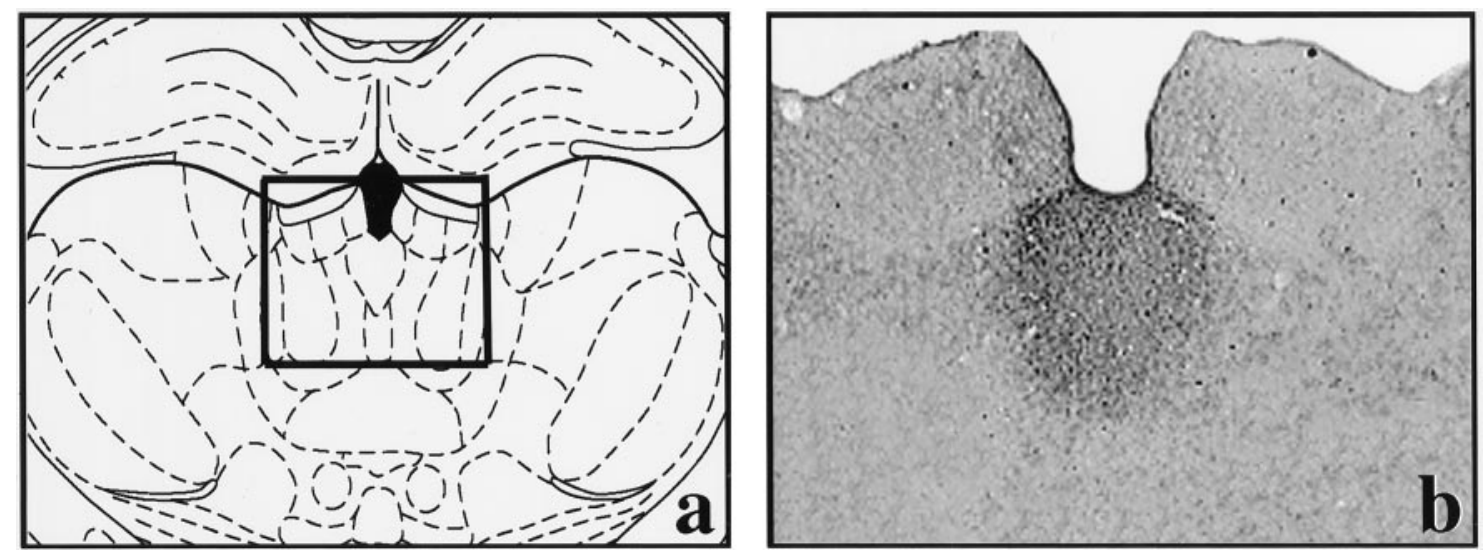

Figure 1. A representative injection of fluorogold in the posterior PVTh $[-3.30 \mathrm{~mm}$ from bregma based on Paxinos and Watson (1986) in $a]$ and visualized immunocytochemically in $b$ (see Materials and Methods). In the experiments presented here, fluorogold injections were limited to the middle/posterior divisions of the PVTh.

while the control animals remained undisturbed. On day 8 , a 31 ga injection cannula was inserted into the guide cannula so that it protruded $1 \mathrm{~mm}$ below its tip, aimed just into the dorsal portion of the middle/ posterior PVTh. Half of the control and half of the chronically stressed animals were injected with the CCK-B receptor antagonist PD 135,158 (Hughes et al., 1990) at $62 \mathrm{ng}$ in $200 \mathrm{nl}$ [doses in this range have been used previously by Popoli et al. (1995)] over 1 min. Remaining rats were injected with $200 \mathrm{nl}$ of vehicle $(0.9 \%$ saline $)$. Thirty minutes after the injections, all animals were placed in a restrainer, and a blood sample was immediately taken from a tail vein (the 0 min time point). Samples were also collected at 15 and 30 min during restraint. Animals were then removed from the restrainer and replaced in their home cages. Thirty minutes later (at 60 min), all animals were killed by decapitation. There were $7-14$ rats per group in this study.

\section{Experiment 3b: procedure}

A separate group of animals was subjected to the following procedure. On day 8, half of the CTL and CHR animals were injected with sulfated CCK-8 [CCK-8s, the high-affinity agonist to the CCK-A receptor (Benedetti, 1997)] at a dose of $10 \mathrm{ng}$ in $200 \mathrm{nl}$ (Bloch et al., 1989; Crawley, 1992), and the other half received $200 \mathrm{nl}$ of vehicle (0.9\% saline). Thirty minutes later, all animals were exposed to restraint and sampled as above. There were 5-13 rats per group in this study.

\section{Experiment 3c: procedure}

A separate group of animals was subjected to the following procedure. On day 8, half of the CTL and CHR animals were injected with unsulfated CCK-8 [the high-affinity agonist to the CCK-B receptor (Benedetti, 1997)] at a dose of $10 \mathrm{ng}$ in $200 \mathrm{nl}$ (Bloch et al., 1989; Crawley, 1992), and the other half received $200 \mathrm{nl}$ of vehicle. Thirty minutes later, all animals were exposed to restraint and sampled as above. There were $6-11$ rats per group in this study.

\section{Guide cannula implantation into the PVTh}

Rats were anesthetized with a mix of ketamine, xylazine, and acepromazine (77:1.5:1.5 mg/ml, i.p., at $0.1 \mathrm{ml} / 100 \mathrm{gm}$ of body weight) and placed in a stereotaxic apparatus with the skull flat (the tooth bar at $-3.3 \mathrm{~mm}$ ). A 28 ga guide cannula was lowered down the midline to the following coordinates: anteroposterior, $-2.8 \mathrm{~mm}$, and dorsoventral, $-5.3 \mathrm{~mm}$. A 31 ga dummy cannula cut to the length of the guide cannula was inserted into the guide cannula.

\section{Confirmation of PVTh cannula implantations}

At the end of Experiments 3a-c, all animals were decapitated; brains were collected, post-fixed in $4 \%$ formalin followed by $30 \%$ sucrose, and sliced at $30 \mu \mathrm{m}$ on a sliding microtome. One series of sections was stained with cresyl violet to visualize placement of the cannula. All brains were examined in a blind manner. To score a "hit" of an injection into the PVTh, there had to be histological evidence of the needle trajectory and clear damage of the ependyma of the ventricle overlying the PVTh. If ependymal damage was not apparent, the injectate was assumed to have been delivered into the ventricle, and the rat was scored as a "miss." Injection tracks lateral or ventral to the PVTh were also scored as misses. Consequently, approximately half of the animals injected with CCK agonists or antagonists in Experiment 3 were scored as misses.

\section{ACTH and corticosterone radioimmunoassays}

Plasma ACTH was measured by radioimmunoassay using a specific antiserum generously donated by Dr. William Engeland (University of Min- nesota) at a final dilution of 1:120,000 and ${ }^{125} \mathrm{I}-\mathrm{ACTH}$ as a tracer (Incstar, Stillwater, MN). The ACTH antiserum cross-reacts $1 \%$ with ACTH1-39, ACTH1-18, and ACTH 1-24 but not with ACTH1-16, B-endorphin, $\alpha$-MSH, or B-lipotropin $(<0.1 \%)$. Plasma was incubated for $48 \mathrm{hr}$ at $40^{\circ} \mathrm{C}$ with antiserum and tracer; then precipitation serum (Peninsula Laboratories, Belmont, CA) was added and incubated for $2 \mathrm{hr}$. Bound peptide was obtained by centrifugation at $5000 \times g$ for $45 \mathrm{~min}$. The minimum level of detection of the assay was $10 \mathrm{pg} / \mathrm{ml}$. Plasma B was measured using a kit from Incstar.

\section{Drugs}

PD 135,158, the CCK-B receptor antagonist (Research Biochemicals, Natick, MA), was dissolved in $0.9 \%$ saline and injected at a dose of 62.5 $\mathrm{ng} / 200 \mathrm{nl}$ into the PVTh. Sulfated and unsulfated CCK-8 (BACHEM), the CCK-A and -B receptor agonists, respectively, were used in equimolar doses (Crawley, 1992), initially dissolved in $\mathrm{NaHCO}_{3}$ and brought up to volume in $0.9 \%$ saline. CCK-8s and CCK- 8 were injected $(10 \mathrm{ng} / 200 \mathrm{nl})$ into the PVTh. Saline $(0.9 \%)$ served as the vehicle injection in all experiments.

\section{Statistical analyses}

Experiment 2. A one-way ANOVA (control vs chronically stressed groups) was performed to determine whether chronic stress altered the density of CCK-B receptor mRNA in the PVTh. There were five animals per group in this study.

Experiment 3. Because the purpose of this experiment was to examine the effects of injection of CCK receptor antagonist and agonists into the PVTh on HPA activity in CTL and CHR animals, each drug-injected group was compared with its vehicle-injected control and with the missedinjection groups. Data were analyzed using two-way ANOVA [group (drug-injected vs vehicle-injected vs missed injections) $\times$ time (repeated variable)]. Scheffé post hoc tests were used when the overall $p$ was $<0.05$.

\section{RESULTS}

\section{Experiment 1}

Because our previous data indicated a specific role for the posterior division of the PVTh in regulating facilitated HPA activity (Bhatnagar and Dallman, 1998), our principal goal was to determine the sources of afferent inputs to this particular division of the PVTh. We found that in three rats the dense core of the fluorogold deposit was in the pPVTh, with some diff usion into the middle division but none in the anterior PVTh. Brains in which more than the outer margins of fluorogold diffusion were localized outside the pPVTh into the lateral or medial habenulae or into other thalamic nuclei or in which the core of the fluorogold deposit was not found in the pPVTh at all were not examined further. In all animals injected with fluorogold into the pPVTh, the pattern and intensity of fluorogold accumulation within the forebrain and brainstem structures were similar. In addition, no pattern of fluorogold labeling was found in the brain that could be interpreted as resulting from fluorogold deposits into other thalamic nuclei. The extent of spread of the fluorogold injection into the PVTh is shown in a representative animal in Figure 1. 

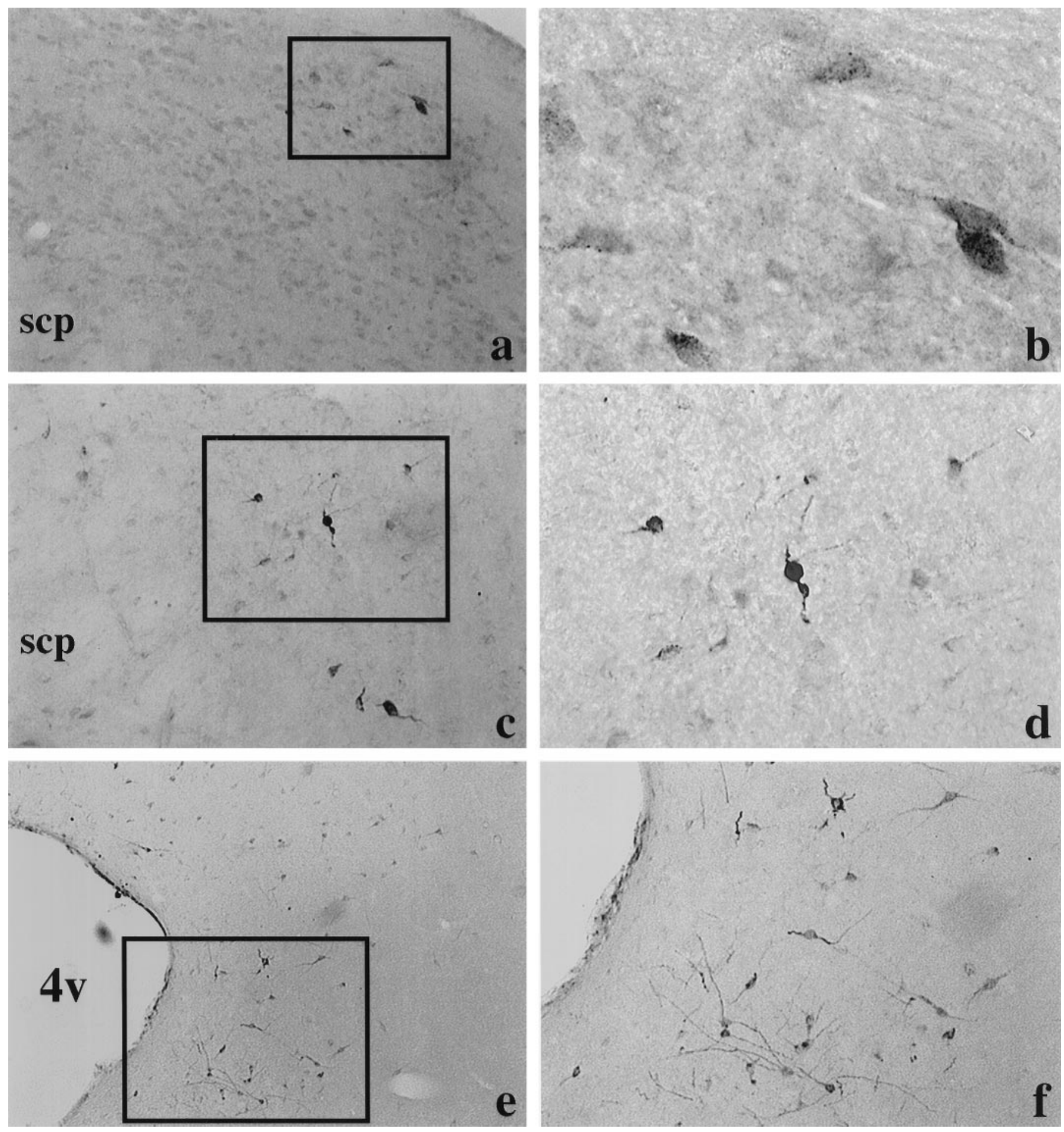

Figure 2. Fluorogold-labeled cells in the dorsal ( $a, b$; approximately $-9.3 \mathrm{~mm}$ from bregma) and central ( $c$, $d$; approximately $-8.72 \mathrm{~mm}$ from bregma) divisions of the lateral parabrachial and in the periaqueductal gray $(e, f ;$ approximately $-7.64 \mathrm{~mm}$ from bregma) after fluorogold injection into the pPVTh. Pictures on the right $(b, d, f)$ are higher magnifications of the boxed areas shown on the left $(a, c, e)$. Coordinates are based on the atlas of Paxinos and Watson (1986). scp, Superior cerebellar peduncle; $4 v$, fourth ventricle.

\section{Retrograde labeling after pPVTh fluorogold injections}

The pattern of fluorogold labeling observed in this study is in strong agreement with that of previous surveys of afferent inputs to the PVTh after injections of fluorogold into the medial/posterior PVTh (Eberhart et al., 1985; Otake and Nakamura, 1995; Otake and Ruggiero, 1995).

Hypothalamus and limbic structures. Scattered fluorogold-labeled cells were found in the PVN, arcuate nucleus, and amygdala. Heavy labeling was observed in the zona incerta (data not shown).
Brainstem. In the lateral parabrachial nucleus (Fig. $2 a-d$ ), moderate numbers of fluorogold-labeled cells were found in the central division, and somewhat lower numbers were found in the dorsal division [divisions based on Saper and Loewy (1980)]. Some fluorogold-labeled cells were also found in the locus coeruleus. Heavy fluorogold staining was observed in the lateral, dorsolateral, and ventrolateral divisions of the periaqueductal gray (Fig. 2e,f). More caudally, fluorogold-labeled cells were only seen in the ventrolateral portion of this region. Moderate numbers of fluorogold- 

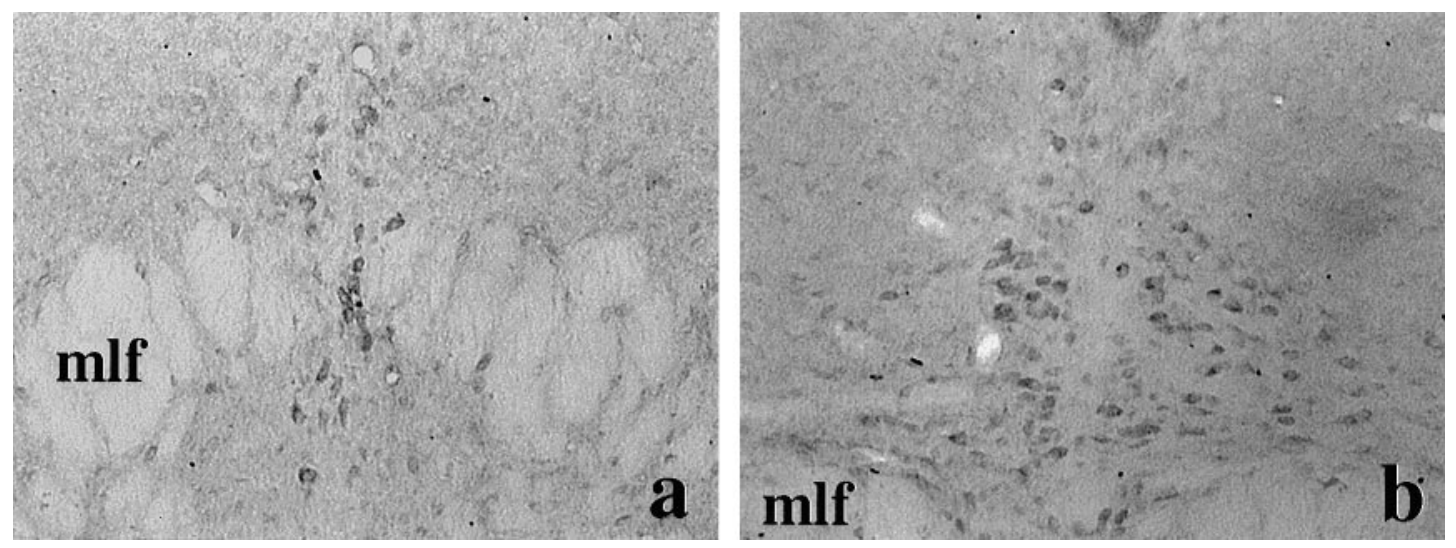

Figure 3. Fluorogold-labeled cells in the caudal (approximately $-9.16 \mathrm{~mm}$ from bregma) levels of the dorsal raphe after fluorogold injection into the pPVTh. $b$ is a higher magnification of $a$. Coordinates are based on the atlas of Paxinos and Watson (1986). mlf, Medial longitudinal fasciculus.

labeled cells were found throughout the rostrocaudal extent of the dorsal raphe, but none were found in the median raphe (Fig. 3). Some fluorogold-labeled cells were observed in the supramammillary area, and higher numbers were in the lateral mammillary nucleus. Fluorogold-labeled cells were also found in the ventral tegmental area (VTA), but none were in the substantia nigra.

\section{Regions containing double-labeled fluorogold and CCK mRNA cells}

Through those regions described above that were found to stain for fluorogold, a second series of sections was stained for fluorogold and processed for CCK mRNA. Only a few areas contained cells that were double labeled for fluorogold and CCK mRNA. Some of the fluorogold cells in the central division of the lateral parabrachial nucleus expressed CCK mRNA, whereas most of the fluorogold-labeled cells in the dorsal division also expressed CCK mRNA (Fig. $4 a-d$ ). A few double-labeled cells were observed in the ventrolateral, but none in the dorsal, periaqueductal gray (Fig. $4 e, f)$. Most fluorogold-labeled cells in the dorsal raphe at its caudal extent also expressed CCK mRNA (Fig. 4g,h); however, we saw no doubly labeled cells in the more rostral levels of the dorsal raphe. Fluorogold-labeled cells in the locus coeruleus, supramammillary region, mammillary nucleus, and VTA regions were not found to contain CCK mRNA.

\section{Experiment 2: CCK-B receptor mRNA in the PVTh}

CCK-B receptors were localized throughout the entire extent of the PVTh, and similar densities of receptor expression were found in the anterior, midde, and posterior divisions of the PVTh. However, there were no significant differences in CCK-B receptor mRNA between control and chronically stressed animals in any of the three levels of the PVTh (Fig. 5, Table 1).

\section{Experiment 3}

\section{Histology of injection sites}

Figure 6 shows micrographs of the pPVTh region from three rats. Figure $6 a$ shows clear evidence that the injection needle pierced the ependyma, suggesting that the injectate was delivered directly into PVTh parenchyma. This animal was grouped in the hit category. Figure $6 b$ shows a brain in which the trajectory of the injection needle can be seen, but there is no evidence of a break in the ependymal lining of the ventricle. This animal was grouped in the missed category. In Figure $6 c$, the injection needle track is lateral to the PVTh proper and is also misplaced more anteriorly in the nucleus. This animal was also grouped in the missed category. Similar criteria were used to categorize all cannula placements resulting in three groups of control and chronically stressed rats: vehicle injected into the PVTh, drug injected into areas other than the PVTh (missed), and drug injected into the PVTh.
$A C T H$ responses to the $C C K-B$ receptor antagonist $P D 135,158$

In both control and chronically stressed animals, ACTH and corticosterone $(\mathrm{B})$ responses to restraint were similar after injection of PD 135,158 into areas other than the PVTh and after vehicle injection into the PVTh. Thus, the effects of injecting PD 135,158 into the PVTh were specific to this nucleus and were not caused by diff usion through the cerebrospinal fluid and action elsewhere or by its effect on other nearby nuclei (Fig. 7).

Injection of the CCK-B receptor antagonist PD 135,158 into the PVTh did not significantly affect plasma ACTH responses to restraint in control animals compared with the responses with vehicle injections or injections of PD 135,158 into other areas. In marked contrast, injection of PD 135,158 into the PVTh significantly increased ACTH secretion after restraint in the chronically stressed rats. ACTH tended to increase at $15 \mathrm{~min}(p=0.08)$ and significantly increased at $30 \mathrm{~min}$ [Fig. $7 ; F_{(1,11)}=3.48 ;{ }^{*} p=0.04$ ] in CHR animals compared with the response in the vehicleinjected and missed groups. B levels were not significantly affected by PD 135,158 injected in either CTL or CHR animals, probably because ACTH levels (300-500 pg/ml) were above the saturation level for the adrenal corticosterone response (Dallman et al., 1987) (data not shown).

\section{$A C T H$ responses to the unsulfated $C C K$ agonist $C C K-8$}

Injection into the PVTh of the CCK-B receptor-preferring agonist CCK-8 did not significantly alter ACTH or B responses to restraint in either CTL or CHR animals (Fig. 8).

\section{$A C T H$ and $B$ responses to the sulfated CCK agonist CCK-8s}

Injection of the CCK-A receptor-preferring agonist CCK-8s into the PVTh did not significantly alter ACTH or B responses to restraint in either CTL or CHR animals (Fig. 9).

\section{DISCUSSION}

Taken as a whole, our results show that the posterior PVTh inhibits ACTH responses to acute stress via stimulation of CCK-B receptors by CCK released from a distinct set of brain regions consisting of the lateral parabrachial, periaqueductal gray, and/or dorsal raphe. These CCKergic inputs to the pPVTh are specifically stimulated by acute stress superimposed on a background of previous chronic stress, because there was no effect of blockade of CCK-B receptors on ACTH secretion in control animals. These effects are not caused by differences in the expression of CCK-B receptor mRNA in the pPVTh. Thus, activation of PVTh CCK-B receptors by CCK, probably released from neurons in brainstem areas, represents one mechanism by which previous experience with chronic stress alters subsequent HPA activity.

The posterior PVTh responds to multimodal stimuli and has been characterized as a part of the visceral limbic system (Turner 

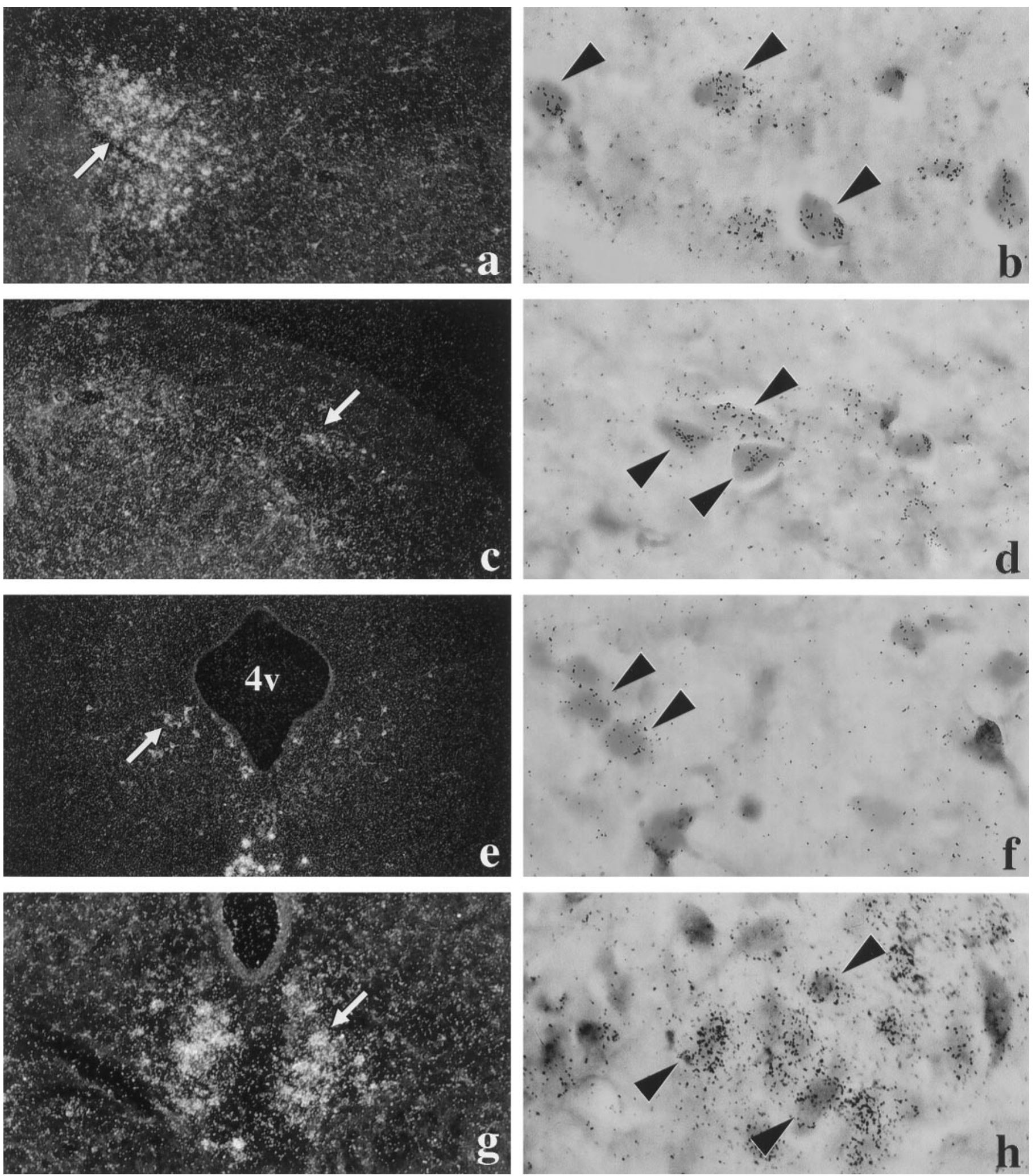

Figure 4. Characterization of CCK-expressing afferents to the pPVTh using fluorogold injections into the pPVTh and in situ hybridization for CCK mRNA. Left, Dark-field photomicrographs illustrating that CCK mRNA is expressed with varying degrees of prominence in the central and dorsal lateral parabrachial nuclei $(a, c$, respectively), the ventrolateral periaqueductal gray (PAG; $e$ ), and the caudal dorsal raphe $(g)$. Right, Higher magnification bright-field views of the regions on the left (see arrows) showing the distribution of the CCK transcript relative to that of retrogradely labeled fluorogold afferents. Many fluorogold-labeled neurons in the parabrachial $(b, d)$ and caudal dorsal raphe nuclei $(h)$ are CCK positive (see arrowheads). Only occasional instances of fluorogold-CCK colocalization were encountered in the ventrolateral PAG $(f)$. See Results for more details. $4 v$, Fourth ventricle. 

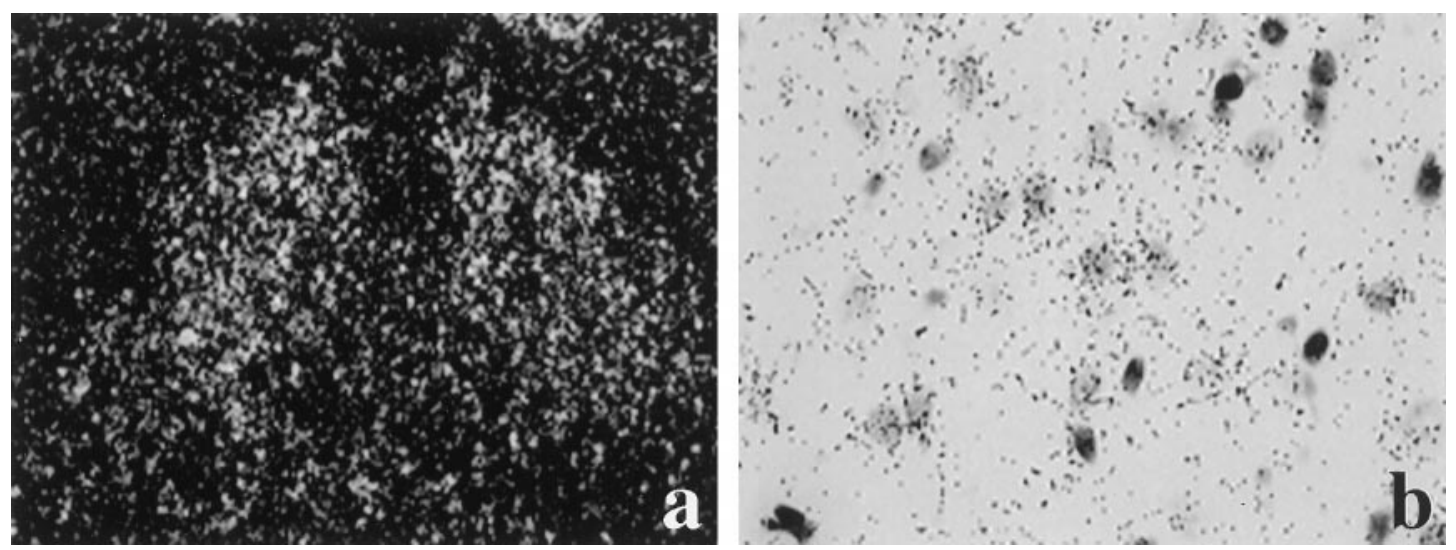

Figure 5. Dark-field $(a)$ and bright-field $(b)$ images of the CCK receptor mRNA distribution in the posterior division of the PVTh (approximately -3.30 $\mathrm{mm}$ from bregma). Neurons in $b$ are lightly stained with cresyl violet. Chronic stress did not alter CCK-B receptor mRNA in any division of the PVTh. Coordinates are based on the atlas of Paxinos and Watson (1986).

Table 1. CCK-B receptor mRNA in the three divisions of the PVTh in control animals and in animals exposed to chronic, intermittent cold stress

\begin{tabular}{llr} 
& Control & \multicolumn{1}{c}{$\begin{array}{l}\text { Chronic } \\
\text { stress }\end{array}$} \\
\hline Anterior PVTh & $11.4 \pm 2.0$ & $9.3 \pm 1.4$ \\
Midde PVTh & $16.2 \pm 1.8$ & $12.5 \pm 0.9$ \\
Posterior PVTh & $16.5 \pm 1.6$ & $17.1 \pm 3.7$
\end{tabular}

Chronic stress did not change CCK-B receptor expression in any division of the PVTh. Values are mean optical density \pm SEM.

and Herkenham, 1991; Otake et al., 1994). It receives input from the nucleus tractus solitariius and parabrachial nuclei (Saper and Loewy, 1980; Fulwiler and Saper, 1984; Otake and Ruggiero, 1995) and projects preferentially to the basomedial, basolateral, and central nuclei of the amygdala (Su and Bentivoglio, 1990; Turner and Herkenham, 1991; Moga et al., 1995). To identify afferent projections to the posterior PVTh that may contribute to effects of previous chronic stress on stimulated ACTH secretion, we injected the retrograde tracer fluorogold into this pPVTh. We focused on the results of tracer injected into the posterior division of the PVTh because this site specifically exhibits increased neuronal activity in response to restraint in chronically stressed animals and it projects preferentially to the amygdala subnuclei that also showed increased neuronal activity in chronically stressed compared with control rats (Bhatnagar and Dallman, 1998).

We found fluorogold-labeled cells in the amygdala, zona incerta, scattered hypothalamic sites, supramammillary area, and VTA after application of fluorogold into the pPVTh. We also found fluorogold-containing neurons in a number of regions further caudal in the brainstem, including the lateral parabrachial nuclei, periaqueductal gray, and the pontine dorsal raphe (B6). Labeling of cells with fluorogold in most of these structures has been shown previously after injection of this tracer into the medial/posterior division of the PVTh (Eberhart et al., 1985; Otake and Nakamura, 1995; Otake and Ruggiero, 1995).

However, we became particularly interested in the lateral parabrachial, dorsal raphe, and periaqueductal gray for two reasons. First, our previous studies showed a tendency for preferential increases in the lateral parabrachial and dorsal raphe in the numbers of Fos-positive cells after acute restraint in chronically stressed rats compared with naïve controls (Bhatnagar and Dallman, 1998). Second, the lateral parabrachial and dorsal raphe nuclei as well as the periaqueductal gray are important in mediating gustatory responses, analgesia, and arousal, among other functions (Saper and Loewy, 1980; Eberhart et al., 1985; Bandler and Shipley, 1994; De Oca et al., 1998; Lonstein et al., 1998). These nuclei have widespread connections with brainstem and spinal sensory areas and with hypothalamic, cortical, and limbic cell groups. They also have all been implicated in the regulation of ACTH secretion (Ward et al., 1976; Bereiter and Gann, 1990; Carlson et al., 1994). Additionally, the lateral parabrachial, dorsal raphe, locus coeruleus, and periaqueductal gray all provide the amygdala, the paraventricular nuclei of the hypothalamus, and the PVTh with sensory input related to these functions (Fulwiler and Saper, 1984; Floyd et al., 1996). Thus, it seemed likely that projections from these brainstem cell groups to the PVTh would be important in terms of the functional regulation of HPA activity.

We approached our investigation of the role of these brainstem projections to the PVTh by determining potential peptides or neurotransmitters contained in these projections. Although the PVTh is richly innervated by peptidergic and aminergic fibers (Freedman and Cassell, 1994; Otake and Ruggiero, 1995), CCK heavily innervates the posterior PVTh (Hunt et al., 1987; Freedman and Cassell, 1994; Otake and Ruggiero, 1995), and the PVTh is decorated with CCK receptors, primarily CCK-B (Harro et al., 1993; Honda et al., 1993; Benedetti, 1997). In common, the lateral parabrachial, dorsal raphe, and periaqueductal gray synthesize CCK (Vanderhaeghen, 1985). Furthermore, CCK has effects on HPA activity and is well known for its effects on food intake, and we have shown previously that the pPVTh is involved in both these functions (Bhatnagar and Dallman, 1998, 1999). Together, these studies pointed to a potentially important role for CCK cell bodies in the lateral parabrachial, dorsal raphe, and periaqueductal gray as mediators for the pPVTh regulation of HPA activity. We first determined whether these brainstem areas did indeed provide CCK inputs to the PVTh by examining the distribution of fluorogold-labeled cells that also synthesized CCK. Of the regions containing fluorogold-labeled cells, only cells in the central and dorsal divisions of the lateral parabrachial nuclei, the ventrolateral periaqueductal gray, and caudal dorsal raphe nuclei also contained CCK mRNA. Thus, these structures constituted the sources of afferent CCK inputs to the PVTh.

We next tested whether the CCK-containing inputs to the PVTh were involved in regulating HPA activity by blocking the predominant CCK-B receptors in the PVTh with injections of the CCK-B antagonist PD 135,158. Blockade of PVTh CCK-B receptor selectively enhanced ACTH responses to restraint in chronically stressed animals but had no effect on ACTH responses in control animals. Thus, blocking the effects of endogenously released CCK in the PVTh is selective to the state of chronic stress. Furthermore, we found that this effect is probably not attributable to a change in CCK-B receptor expression in the PVTh as a consequence of chronic stress exposure, because CCK-B receptor mRNA was not different between control and chronically stressed animals. Therefore, as in our previous findings with lesions of the PVTh, blockade of CCK-B receptors in this region provides further evidence of the 

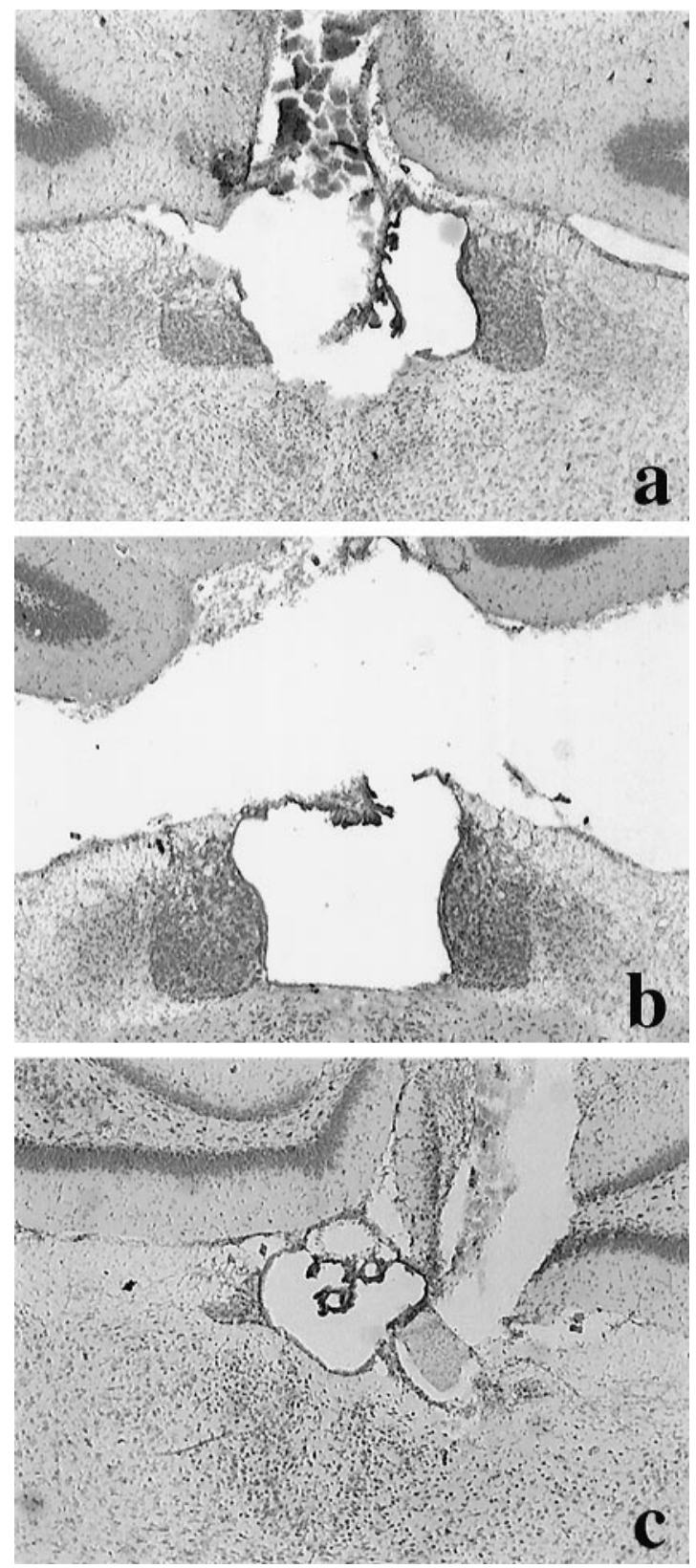

Figure 6. Representative photomicrographs of the track of an injector cannula placed in the pPVTh $(a)$ and in the ventricle $(b)$ and a missed placement lateral to the PVTh $(c)$.

PVTh as a site at which previous stress information is processed. That is, the PVTh has a state-dependent effect on the regulation of novel, acute stress-induced ACTH secretion.

On the basis of these effects of the CCK-B receptor antagonist, we expected that injection of a CCK-B receptor agonist into the PVTh before restraint might further inhibit the ACTH response. However, injection into the PVTh of agonists specific either to CCK-B [unsulfated CCK-8 (Benedetti, 1997)] or CCK-A [sulfated CCK-8 (Benedetti, 1997)] receptors had no effect on ACTH responses to restraint in either control or chronically stressed animals. It may be that the timing or dose of the agonist administered was inappropriate although both have been used in studies in which similar doses of these agonists were effective when microinjected into specific brain regions (Bloch et al., 1989; Crawley, 1992). Alternatively, it is possible that CCK effects in the paraventricular thalamus require corelease of another transmitter. For example, serotonin from the raphe or CRF from the parabrachial (Otake and Nakamura, 1995) may act in concert with CCK at the paraventricu-

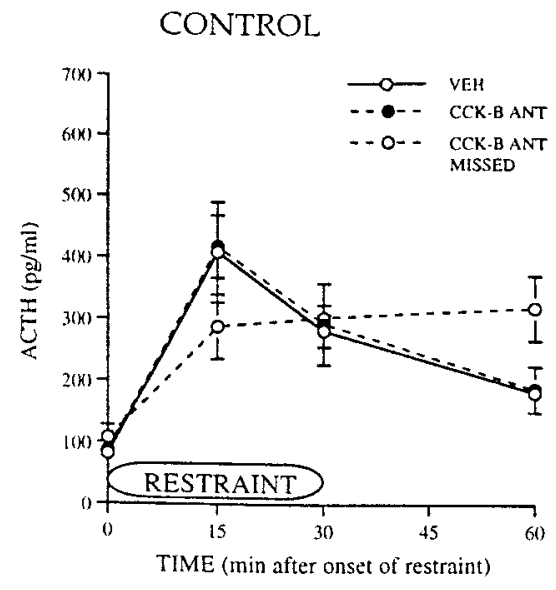

CHRONIC STRESS

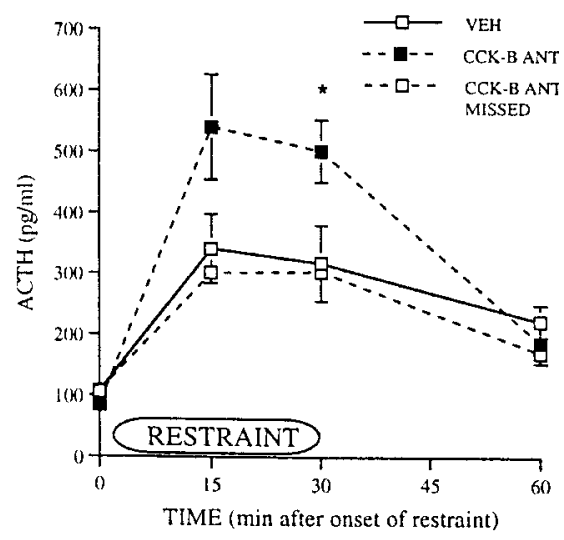

Figure 7. ACTH responses during and after a $30 \mathrm{~min}$ period of restraint in control animals and in animals exposed to chronic, intermittent cold stress. Control and chronically stressed animals had PVTh injections of either vehicle $(V E H)$ or the CCK-B receptor antagonist PD 135,158 (CCK-B ANT) or injections of the antagonist into areas other than the PVTh (CCK-B ANT MISSED). For control groups, $V E H, n=6-7 ; C C K-B$ $A N T, n=10 ; C C K-B A N T$ MISSED,$n=4-5$. For chronic stress groups, $V E H, n=6-7 ; C C K-B A N T, n=7 ; C C K-B$ ANT MISSED, $n=4-7$. ${ }^{*} p \leq 0.05$.

lar thalamus in chronically stressed rats but may not be released in control rats since neither blockade nor stimulation had any effect in this group. Thus, we hypothesize that, in chronically stressed animals, the CCK input to the pPVTh is specifically activated and that the pPVTh then further activates an upstream pathway that ultimately acts at the PVN to determine HPA responsiveness in chronically stressed individuals.

The critical controls in these microinjection studies were provided by results from the injection of drug into areas other than the PVTh, our missed groups. In Experiment 3 there were no significant differences between injection of vehicle into the PVTh and injection of the drugs into areas other than the PVTh. These results support our contention that any effects of injecting the CCK-B antagonist or either agonist into the PVTh are specific to the actions of these drugs in the PVTh and not caused by an action at some other site.

On the basis of the present data, we propose that ascending CCKergic pathways originating in the lateral parabrachial, dorsal raphe, and/or periaqueductal gray to the $\mathrm{pPVTh}$ are recruited in chronically stressed rats exposed to a new stress stimulus. This novel stressor results in the release of CCK that acts via association with CCK-B receptors in the PVTh to cause inhibition of HPA responses to stress. The lack of effect of either CCK-B receptor agonists or antagonists in control animals suggests that the CCK pathways to the PVTh are not recruited in control animals in 


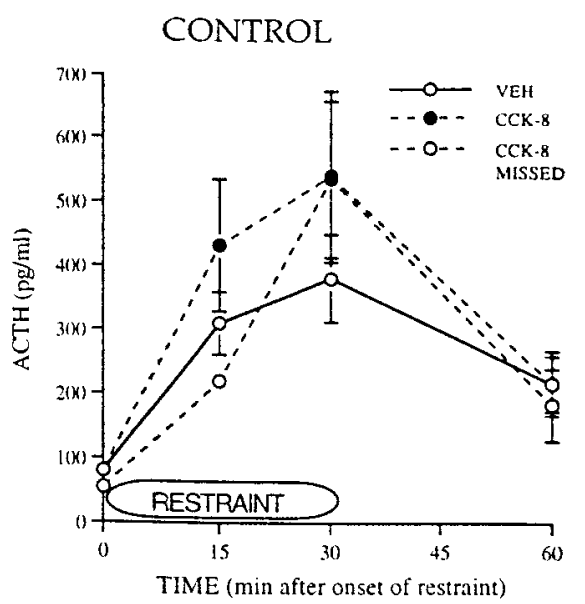

\section{CHRONIC STRESS}

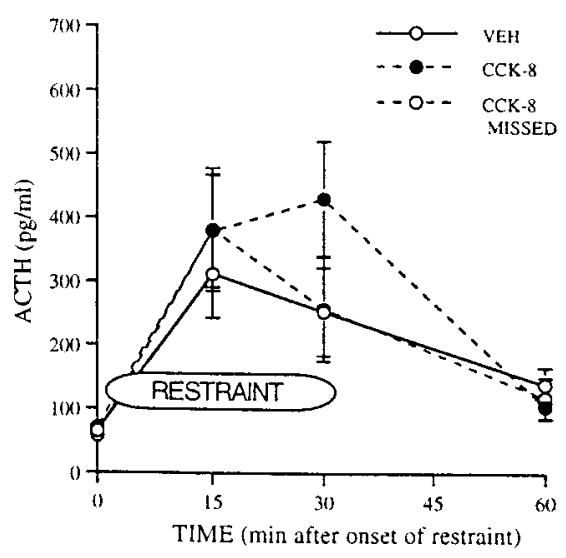

Figure 8. ACTH responses during and after a $30 \mathrm{~min}$ period of restraint in control animals and in animals exposed to chronic, intermittent cold stress. Control and chronically stressed animals had PVTh injections of either vehicle $(V E H)$ or the CCK-B receptor agonist unsulfated CCK-8 $(C C K-8)$ or injections of the agonist into areas other than the PVTh $(C C K-8$ $M I S S E D)$. For control groups, $V E H, n=6 ; C C K-8, n=6 ; C C K-8$ MISSED, $n=3$. For chronic stress groups, $V E H, n=6-7 ; C C K-8, n=5 ; C C K-8$ MISSED, $n=6$.

response to acute restraint. Furthermore, it is likely that this recruitment of ascending CCK pathways to the pPVTh in chronically stressed animals occurs only under stimulated conditions of a novel stressor and not under basal conditions because basal HPA activity is not different between control and chronically stressed animals. Thus, after novel stress, the magnitude of the ACTH response is constrained by release of CCK into the pPVTh in chronically stressed animals even in the presence of the known facilitatory effect of previous stress on ACTH secretion (Akana and Dallman, 1997).

Our results do not preclude the possibility that neurotransmitters or peptides, other than CCK, are released into the pPVTh and either constrain or produce facilitation of HPA activity. Indeed, the existence of afferents to the pPVTh originating in the locus coeruleus and dorsal raphe would suggest that norepinephrine and serotonin may also play a role in PVTh regulation of HPA activity under chronic stress conditions. Nevertheless, our data suggest an important role for CCK in this process. Together, the present results and our related work demonstrate a mechanism by which plasticity in the regulation of HPA activity occurs as a consequence of previous chronic stress. There is recruitment of CCK pathways innervating the PVTh that occurs exclusively in animals that have experienced previous chronic stress. Because of the limbic projections of the PVTh, it is likely that this plasticity produced by chronic stress is not unique to regulation of the HPA axis but might

\section{CONTROL}

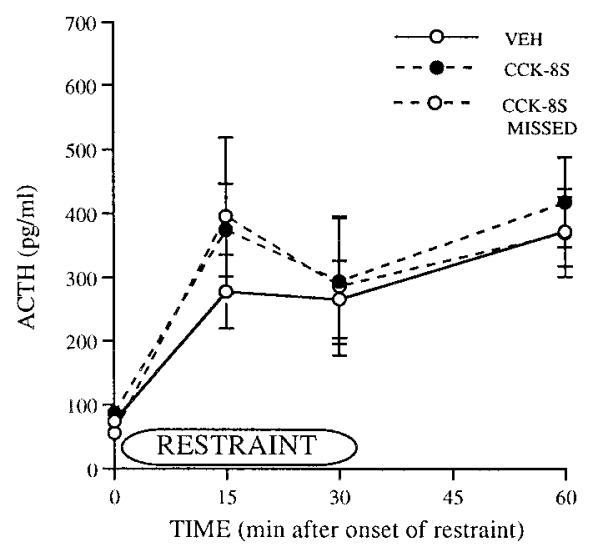

CHRONIC STRESS

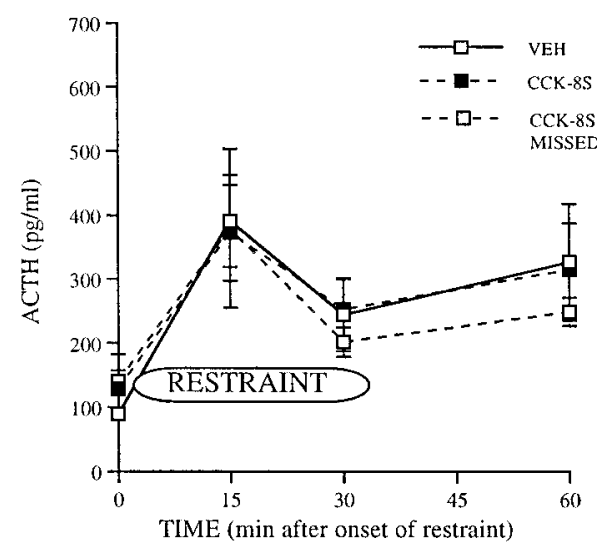

Figure 9. ACTH responses during and after a $30 \mathrm{~min}$ period of restraint in control animals and in animals exposed to chronic, intermittent cold stress. Control and chronically stressed animals had PVTh injections of either vehicle $(V E H)$ or the CCK-A receptor agonist sulfated CCK-8 $(C C K-8 S)$ or injections of the agonist into areas other than the PVTh (CCK-8S MISSED). For control groups, $V E H, n=7 ; C C K-8 S, n=6$; $C C K-8 S M I S S E D, n=4$. For chronic stress groups, $V E H, n=5-6 ; C C K-8 S$, $n=7$; CCK-8S MISSED, $n=3$.

also occur in neural circuits that underlie the effects of chronic stress on anxiety and fear-related behavior, energy balance (Bhatnagar and Dallman, 1999), and sympathetic (Bhatnagar et al., 1995) and immune function (Bhatnagar et al., 1996), as well as behavioral and cardiovascular responses to painful stimuli (Bhatnagar et al., 1998). Our current results provide an anatomic and neuropeptide framework with which to explore further the central mechanisms by which environmental events such as chronic stress can alter subsequent physiology and behavior.

\section{REFERENCES}

Akana SF, Dallman MF (1997) Chronic cold in adrenalectomized, corticosterone (B)-treated rats: facilitated corticotropin responses to acute restraint emerge as B increases. Endocrinology 138:3249-3258.

Akana SF, Hanson ES, Horsley CJ, Strack AM, Bhatnagar S, Bradbury MJ, Milligan ED, Dallman MF (1996) Clamped corticosterone (B) reveals the effect of endogenous $\mathrm{B}$ on both facilitated responsivity to acute restraint and metabolic responses to chronic stress. Stress 1:33-49.

Armario A, Lopzez-Calderon A, Jolin T, Balasch J (1986) Response of anterior pituitary hormones to chronic stress. The specificity of adaptation. Neurosci Biobehav Rev 10:245-250.

Bandler R, Shipley MT (1994) Columnar organization of the midbrain periaqueductal gray: modules for emotional expression? Trends Neurosci $17: 379-389$

Benedetti F (1997) Cholecystokinin type A and type B receptors and their modulation of opioid analgesia. News Physiol Sci 12:263-268.

Bereiter DA, Gann DS (1990) Comparison of the influence of rostral and 
caudal raphe neurons on the adrenal secretion of catecholamines and on the release of adrenocorticotropin in the cat. Pain 42:81-91.

Bhatnagar S, Dallman MF (1998) Neuroanatomical basis for facilitation of hypothalamic-pituitary-adrenal responses to a novel stressor after chronic stress. Neuroscience 84:1025-1039.

Bhatnagar S, Dallman MF (1999) State-dependent regulation of rhythms in temperature and energy balance by the paraventricular nucleus of the thalamus. Brain Res 851:66-75.

Bhatnagar S, Meaney MJ (1995) Hypothalamic-pituitary-adrenal function in chronic intermittently cold-stressed neonatally handled and non handled rats. J Neuroendocrinol 7:97-108.

Bhatnagar S, Mitchell JB, Betito K, Boksa P, Meaney MJ (1995) Effects of chronic intermittent cold stress on pituitary adrenocortical and sympathetic adrenomedullary functioning. Physiol Behav 57:633-639.

Bhatnagar S, Shanks N, Meaney MJ (1996) Immune responses to sheep red blood cells in chronic intermittently stressed neonatally handled and non handled rats. Dev Psychobiol 29:171-182.

Bhatnagar S, Dallman MF, Basbaum A, Taylor B (1998) The effects of prior chronic stress on cardiovascular responses to acute restraint and formalin injection. Brain Res 797:313-320.

Bloch GJ, Dornan WA, Babcock AM, Gorski RA, Micevych PE (1989) Effects of site-specific CNS microinjection of cholecystokinin on lordosis behavior in the male rat. Physiol Behav 46:725-730.

Carlson DE, Nabavian AM, Gann DS (1994) Corticotropin-releasing hormone but not glutamate elicits hormonal responses from the parabrachial region in cats. Am J Physiol 267:R337-R348.

Chan RKW, Brown ER, Kovacs KJ, Sawchenko PE (1993) A comparison of two immediate-early genes, c-fos and NGFI-B, as markers for functional activation in stress-related neuroendocrine circuitry. J Neurosci 13:5126-5138.

Chastrette N, Pfaff DW, Gibbs RB (1991) Effects of daytime and nighttime stress on Fos-like immunoreactivity in the paraventricular nucleus of the hypothalamus, the habenula, and the posterior paraventricular nucleus of the thalamus. Brain Res 563:339-344.

Crawley JN (1992) Subtype-selective cholecystokinin receptor antagonists block cholecystokinin modulation of dopamine-mediated behaviors in the rat mesolimbic pathway. J Neurosci 12:3380-3391.

Cullinan WE, Helmreich DL, Watson SJ (1996) Fos expression in forebrain afferents to the hypothalamic paraventricular nucleus following swim stress. J Comp Neurol 368:88-99.

Dallman MF, Bhatnagar S (2000) Chronic stress: role of the hypothalamopituitary-adrenal axis. Handbook of physiology, pp 179-210. New York: Oxford UP

Dallman MF, Akana SF, Cascio CS, Darlington DN, Jacobson L, Levin N (1987) Regulation of ACTH secretion: variations on a theme of B. Recent Prog Horm Res 43:113-173.

De Oca BM, DeCola JP, Maren S, Fanselow MS (1998) Distinct regions of the periaqueductal gray are involved in the acquisition and expression of defensive responses. J Neurosci 18:3426-3432.

Eberhart JA, Morrell JI, Krieger MS, Pfaff DW (1985) An autoradiographic study of projections ascending from the midbrain central gray, and from the region lateral to it, in the rat. J Comp Neurol 241:285-310.

Floyd NS, Keay KA, Arias CM, Sawchenko PE, Bandler R (1996) Projections from the ventrolateral periaqueductal gray to endocrine regulatory subdivisions of the paraventricular nucleus of the hypothalamus in the rat. Neuroscience 220:105-108.

Freedman LJ, Cassell MD (1994) Relationship of thalamic basal forebrain projection neurons to the peptidergic innervation of the midline thalamus. J Comp Neurol 348:321-342.

Fulwiler CE, Saper CB (1984) Subnuclear organization of the efferent connections of the parabrachial nucleus in the rat. Brain Res Rev 7:229-259.

Harro J, Vasar E, Bradwejn J (1993) CCK in animal and human research on anxiety. Trends Pharmacol Sci 14:244-249.

Hauger RL, Lorang M, Irwin M, Aguilera G (1990) CRF receptor regulation and sensitization of ACTH responses to acute ether stress during chronic intermittent immobilization stress. Brain Res 532:34-40.

Honda T, Wada E, Battey JF, Wank SA (1993) Differential gene expression of CCKA and CCKB receptors in the rat brain. Mol Cell Neurosci 4:143-154.

Hughes J, Boden P, Costall B, Domeney A, Kelly E, Horwell DC, Hunter JC, Pinnock RD, Woodruff GN (1990) Development of a class of selective cholecystokinin type B receptor antagonists having potent anxiolytic activity. Proc Natl Acad Sci USA 87:6728-6732.

Hunt CA, Seroogy KB, Gall CM, Jones EG (1987) Cholecystokinin innervation of rat thalamus, including fibers to the ventroposterolateral nucleus from dorsal column nuclei. Brain Res 426:257-269.
Imaki T, Shibasaki T, Hottta M, Demura H (1993) Intracerebroventricular administration of corticotropin-releasing factor induces c-fos mRNA expression in brain regions related to stress responses: comparison with pattern of c-fos mRNA induction after stress. Brain Res 616:114-125.

Li HY, Sawchenko PE (1998) Hypothalamic effector neurons and extended circuitries activated in "neurogenic" stress: a comparison of footshock effects exerted acutely, chronically, and in animals with controlled glucocorticoid levels. J Comp Neurol 393:244-266.

Lonstein JS, Simmons DA, Stern JM (1998) Functions of the caudal periaqueductal gray in lactating rats: kyphosis, lordosis, maternal aggression, and fearfulness. Behav Neurosci 112:1502-1518.

Moga MM, Weiss RP, Moore RY (1995) Efferent projections of the paraventricular thalamic nucleus in the rat. J Comp Neurol 359:221-238.

Odio M, Brodish A (1989) Age-related adaptation of pituitaryadrenocortical responses to stress. Neuroendocrinology 49:382-388.

Otake K, Nakamura Y (1995) Sites of origin of corticotropin-releasing factor-like immunoreactive projection fibers to the paraventricular thalamic nucleus in the rat. Neurosci Lett 201:84-86.

Otake K, Ruggiero DA (1995) Monoamines and nitric oxide are employed by afferents engaged in midline thalamic regulation. $\mathrm{J}$ Neurosci 15:1891-1911.

Otake K, Reis DJ, Ruggiero DA (1994) Afferents to the midline thalamus issue collaterals to the nucleus tractus solitarii: an anatomical basis for thalamic and visceral reflex integration. J Neurosci 14:5694-5707.

Ottenweller JE, Natelson BH, Pitman DL, Drastal SD (1989) Adrenocortical and behavioral responses to repeated stressors: toward an animal model of chronic stress and stress-related mental illness. Biol Psychiatry 26:829-842.

Paxinos G, Watson C (1986) The rat brain in stereotaxic coordinates, Second Edition. Sydney: Academic.

Pitman DL, Ottenweller JE, Natelson BH (1988) Plasma corticosterone levels during repeated presentation of two intensities of restraint stress: chronic stress and habituation. Physiol Behav 43:47-55.

Popoli P, Reggio R, Pezzola A, Scotti de Carolis A (1995) The stimulation of cholecystokinin receptors in the rostral nucleus accumbens significantly antagonizes the EEG and behavioural effects induced by phencyclidine in rats. Psychopharmacology (Berl) 120:156-161.

Saper CB, Loewy AD (1980) Efferent connections of the parabrachial nucleus in the rat. Brain Res 197:291-317.

Scribner KA, Walker C-D, Cascio CS, Dallman MF (1991) Chronic streptozotocin diabetes in rats facilitates the acute stress response without altering pituitary or adrenal responsiveness to secretagogues. Endocrinology 129:99-108.

Sharp FR, Sagar SM, Hicks K, Lowenstein D, Hisanaga K (1991) c-fos mRNA, Fos, and Fos-related antigen induction by hypertonic saline and stress. J Neurosci 11:2321-2331.

Su H-S, Bentivoglio M (1990) Thalamic midline cell populations projecting to the nucleus accumbens, amygdala and hippocampus in the rat. J Comp Neurol 297:582-593.

Turner BH, Herkenham M (1991) Thalamoamygdaloid projections in the rat: a test of the amygdala's role in sensory processing. J Comp Neurol 313:295-325.

Vanderhaeghen JJ (1985) Neuronal cholecystokinin. In: Handbook of chemical neuroanatomy, Vol 4, GABA and neuropeptides in the CNS, Pt 1 (Bjorklund A, Hokfelt T, eds), pp 406-435. Amsterdam: Elsevier.

van Dijken HH, de Goeij DC, Sutanto W, Mos J, de Kloet ER, Tilders FJ (1993) Short inescapable stress produces long-lasting changes in the brain-pituitary-adrenal axis of adult male rats. Neuroendocrinology 58:57-64.

Viau V, Sawchenko PE (1995) The pattern of cellular activation seen in response to acute restraint suggests commonalities among "neurogenic" stress models. Soc Neurosci Abstr 638:1262.

Wank SA, Pisegna JR, de Weerth A (1992) Brain and gastrointestinal cholecystokinin receptor family: structure and functional expression. Proc Natl Acad Sci USA 89:8691-8695.

Ward DG, Grizzle WE, Gann DS (1976) Inhibitory and facilitatory areas of the rostral pons mediating ACTH release in the cat. Endocrinology 99:1220-1228.

Watts AG, Swanson LW (1989) The combination of in situ hybridization with immunohistochemistry and retrograde tract-tracing. In: Methods in neurosciences, Vol 1 (Conn PM, ed), pp 127-136. New York: Academic.

Young EA, Akana SF, Dallman MF (1990) Decreased sensitivity to glucocorticoid fast feedback in chronically stressed rats. Neuroendocrinology 51:536-542. 